\title{
HUBUNGAN ANTARA STUDENT ENGAGEMENT DAN KECENDERUNGAN DELINKUENSI REMAJA
}

\author{
Jeannefer ${ }^{1}$, Garvin ${ }^{2}$ \\ ${ }^{1}$ Jurusan Psikologi, Universitas Bunda Mulia \\ Email: jeanneferkyara@yahoo.com \\ ${ }^{2}$ Jurusan Psikologi, Universitas Bunda Mulia \\ Email: garvin.goei@gmail.com
}

\begin{abstract}
ABSTRAK
Student engagement mengarah pada totalitas siswa untuk terlibat secara aktif pada aktivitas belajar secara perilaku, kognitif, dan emosional. Siswa yang engaged tidak hanya memiliki performa dan prestasi akademis yang baik tetapi juga dapat membentuk karakter remaja yang lebih proaktif. Di sisi lain, ketidakmampuan siswa untuk terlibat dalam sekolah meningkatkan kecenderungan remaja untuk melampiaskan rasa frustrasiya pada hal-hal lain di luar pelajaran termasuk menunjukkan perilaku yang problematik (Wang \& Fredericks, 2014). Penelitian ini bertujuan untuk menguji hubungan antara student engagement dengan kecenderungan perilaku delinkuensi remaja. Partisipan dalam penelitian terdiri dari 161 orang yang seluruhnya adalah pelajar SMA atau SMK dengan rentang usia 15-19 tahun. Instrumen penelitian yang digunakan adalah skala student engagement yang disusun berdasarkan tiga aspek student engagement dan skala kecenderungan delinkuensi remaja yang disusun berdasarkan empat jenis kenakalan remaja. Hasil uji korelasi Pearson menunjukkan adanya hubungan yang signifikan antara student engagement dengan kecenderungan delinkuensi pada remaja, dengan arah hubungan yang negatif $(r=-0,557, p=$ $0,000<0,05)$. Hal ini berarti, semakin tinggi student engagement, maka kecenderungan delinkuensi remaja menjadi semakin rendah; dan demikian pula dengan sebaliknya, semakin rendah student engagement, kecenderungan delinkuensi remaja semakin tinggi. Peneliti menyarankan agar orangtua maupun pihak sekolah mulai memerhatikan student engagement pada remaja.
\end{abstract}

Kata kunci: student engagement, delinkuensi, remaja

\section{PENDAHULUAN}

\section{Latar Belakang}

Masa remaja merupakan masa perkembangan yang krusial di mana remaja mengalami fase pembentukan identitas diri, berintegrasi secara sosial, dan berkomitmen dalam belajar (Skinner, Kindermann, Connell, dan Wellborn, 2009). Murid yang termotivasi dan engaged pada proses belajar tidak hanya memiliki performa akademis dan prestasi yang lebih baik tapi juga menunjukkan dampak positif pada karakter remaja seperti bersikap lebih positif, proaktif, dan berorientasi pada solusi ketika menghadapi masalah dalam kehidupan sehari-hari. Student engagement merupakan partisipasi siswa secara aktif yang ditandai oleh adanya ketertarikan, investasi serta usaha siswa pada tugas-tugas maupun kegiatan sekolah baik di dalam dan di luar kelas (Wang \& Holcombe, 2010). Menurut Wang \& Holcombe (2010), remaja yang memiliki student engagement akan terlibat dalam sekolahnya, meluangkan waktu untuk mengembangkan potensi akademis mereka, menyalurkan energi mereka pada kegiatan-kegiatan positif yang serta mengerahkan motivasi mereka untuk terlibat secara aktif pada kegiatan dalam kelas maupun luar kelas. Remaja yang terlibat secara aktif dalam pembelajaran akan meningkatkan kemampuan, kompetensi dan nilai-nilai yang membantu mereka dalam melewati masa transisinya ke masa dewasa muda dengan baik.

Namun sayangnya periode ini juga merupakan masa-masa rentan bagi remaja untuk mengalami kemunduran secara akademis karena kurangnya pencapaian dan motivasi belajar, sekaligus meningkatnya kemungkinan pada penggunaan obat-obatan terlarang dan perilaku delinkuensi remaja. Penelitian menunjukkan bahwa para siswa cenderung menunjukkan penurunan keterlibatan akademis saat mereka memasuki sekolah menengah. Beberapa studi memperkirakan sebanyak $40-60 \%$ remaja menunjukkan tanda-tanda kurangnya keterlibatan seperti sikap apatis, 
kurang berusaha, tidak mau terlibat dan tidak memperhatikan. Kegagalan siswa untuk terlibat dalam sekolah dapat menuntun remaja pada konsekuensi mencari pelampiasan dengan bertingkah laku secara problematik dan mengasosiasikan diri dengan lingkungan dan temanteman yang delinkuen (Wang \& Fredericks, 2014). Sarwono (2013) menggambarkan kecenderungan perilaku delinkuen pada umumnya merupakan kegagalan sistem kontrol diri terhadap impuls dan dorongan yang kuat pada masa transisi remaja, impuls tersebut kemudian disalurkan lewat tindakan agresi maupun perbuatan melanggar hukum lain yang di anggap mengandung nilai lebih oleh anak-anak remaja. Mayoritas pelaku tindakan delinkuensi remaja berada dibawah usia 21 tahun dengan angka tertinggi perilaku delinkuensi remaja dilakukan oleh remaja usia 15 hingga 19 tahun.

Perilaku delinkuen remaja memang sudah memprihatinkan. Misalnya, pada awal tahun 2017 lalu, terjadi tawuran antarpelajar di Pasar Rebo yang menewaskan satu orang korban (Amelia dan Hariyanto, 2017) atau pilihan pemuda yang diamankan oleh Polres Jakarta Timur karena diketahui hendak melakukan tawuran dan membawa minuman keras (Hariyanto, 2017). Termasuk pula kejadian remaja yang terkena razia dan diketahui membawa senjata tajam pada bulan Mei silam (Anugrahadi, 2017). Arifin (2017) dalam situs liputan6.com juga melaporkan aksi mesum pelajar-pelajar dan pesta miras yang pernah terjadi di Jakarta Timur. Hal-hal tersebut barulah sedikit saja contoh kenakalan remaja yang terjadi pada tahun 2017 di Jabodetabek. Kasus-kasus lainnya mengenai kenakalan remaja dapat dengan mudah diakses melalui situs-situs berita di internet.

Kecenderungan delinkuensi remaja menurut Kartono (2014) disebabkan oleh faktor internal dan eksternal individu. Secara internal, faktor kecenderungan delinkuensi berkaitan dengan gangguan dari dalam diri seperti gangguan cara berpikir, gangguan perasaan atau emosional, gangguan pengamatan dan tanggapan serta reaksi frustrasi yang negatif pada remaja. Sedangkan pada faktor eksternal yang dapat mempengaruhi perilaku delinkuen seperti hubungan keluarga yang buruk, ketidakpuasan remaja pada sekolah dan sistem pendidikan; juga faktor lingkungan sekitar. Sekolah merupakan faktor yang berperanan penting dalam perkembangan remaja sebab remaja yang berada pada usia sekolah menghabiskan sebagian besar waktunya di sekolah untuk mengikuti kegiatan sekolah ataupun untuk membangun hubungan sosialisasi dengan orang lain. Kartono (2014) menjelaskan bahwa, lamanya anak-anak menghabiskan waktu untuk duduk melakukan kegiatan yang pasif dan membosankan dapat menyebabkan remaja menjadi jenuh dan bersikap apatis. Materi akademik yang kurang menarik dan tidak sesuai aspirasi anak muda jaman sekarang juga dapat mengakibatkan anak menjadi jemu belajar dan lelah secara psikis. Begitu pula apabila guru-guru yang mengajar bersifat acuh tak acuh pada muridnya, memiliki temperamen sering meledak serta tidak peka terhadap kebutuhan atau kesulitan siswanya sangat mungkin untuk menciptakan iklim antipasti bagi siswa dan hilangnya kegairahan belajar pada remaja.

Wang \& Fredericks (2014) menyebutkan bahwa kegagalan siswa untuk terlibat dalam sekolah dapat menuntun remaja pada konsekuensi mencari pelampiasan dengan bertingkah laku secara problematik dan mengasosiasikan diri dengan lingkungan dan teman-teman yang delinkuen. Seiring waktu, keterkaitan antara penarikan diri dari sekolah dan tingkah laku yang problematik secara akumulatif akan membentuk jati diri remaja dan mempengaruhi peningkatan pada perilaku delinkuensi remaja. 


\section{METODE PENELITIAN}

\section{Partisipan Penelitian}

Penelitian ini melibatkan 161 remaja berusia 15 hingga 19 tahun yang berdomisili di Jakarta, tanpa membedakan jenis kelamin, agama, maupun suku bangsa. Teknik pengambilan sampel yang digunakan adalah purposive sampling.

\section{Instrumen Penelitian}

Peneliti menggunakan dua instrumen dalam penelitian ini, yakni skala student engagement dan skala student engagement dan skala kecenderungan delinkuensi remaja. Instrumen yang pertama, yakni skala student engagement disusun oleh peneliti berdasarkan tiga aspek student engagement yang disebutkan oleh Fredricks, Bulmenfeld, dan Paris (2004), yakni: aspek perilaku, aspek emosional, dan aspek kognitif. Alat ukur tersebut terdiri dari 19 butir berupa pernyataan, berskala Likert, dan partisipan menjawab dengan memilih salah satu dari empat pilihan jawaban: "Sangat Sesuai", "Sesuai", "Tidak Sesuai" dan "Sangat Tidak Sesuai". Hasil uji coba menunjukkan bahwa alat ukur ini reliabel $(\alpha=0,792)$.

Pada instrumen kedua, yaitu skala kecenderungan delinkuensi remaja, disusun oleh peneliti berdasarkan empat jenis kenakalan atau delinkuensi remaja, yakni: (1) kenakalan yang menimbulkan korban fisik pada orang lain, (2) kenakalan yang menimbulkan korban materi, (3) kenakalan sosial yang tidak menimbulkan korban di pihak orang lain, dan (4) kenakalan yang melawan status (Jensen dalam Sarwono, 2013). Alat ukur tersebut berskala Likert, terdiri dari 22 butir pernyataan yang dijawab oleh partisipan dengan empat pilihan jawaban, yakni "Sangat Sesuai", "Sesuai", "Tidak Sesuai" dan "Sangat Tidak Sesuai". Hasil uji coba menunjukkan bahwa alat ukur ini tergolong reliabel $(\alpha=0,843)$.

\section{HASIL DAN PEMBAHASAN}

\section{Gambaran umum partisipan berdasarkan usia}

Partisipan dalam penelitian ini berada pada rentang usia 15 hingga 19 tahun. Partisipan yang berusia 15 tahun ada sebanyak 19 orang atau 11,8\% dari total partisipan, sedangkan partisipan yang berusia 16 tahun terdapat 79 orang atau 49,1\% dari total partisipan. Partisipan yang berusia 17 tahun terdapat 51 orang atau sebanyak $31,7 \%$ dari total partisipan. Sedangkan partisipan yang berusia 18 tahun terdapat 11 orang atau $6,8 \%$ dari total partisipan. Usia dengan jumlah partisipan paling sedikit adalah usia 19 tahun yang hanya terdapat 1 orang atau $0,6 \%$ dari total partisipan.

Tabel 1. Gambaran Umum Partisipan Berdasarkan Usia

\begin{tabular}{ccc}
\hline Usia (tahun) & Frekuensi (orang) & Persentase \\
\hline 15 & 19 & 11,8 \\
16 & 79 & 49,1 \\
17 & 51 & 31,7 \\
18 & 11 & 6,8 \\
19 & 1 & 0,6 \\
\hline Total & $\mathbf{1 6 1}$ & $\mathbf{1 0 0}$ \\
\hline
\end{tabular}




\section{Uji normalitas variabel student engagement}

Sebelum melakukan uji korelasi, peneliti melakukan uji normalitas terlebih dahulu. Tujuan dari uji normalitas adalah untuk melihat apakah data terdistribusi secara normal atau tidak normal. Apabila data terdistribusi normal, maka analisis dilakukan dengan menggunakan uji korelasi Pearson (parametrik), namun apabila data tidak terdistribusi dengan normal, maka uji korelasi yang digunakan adalah uji korelasi Spearman (non-parametrik).

Uji normalitas menggunakan uji Kolmogorov-Smirnov. Berdasarkan uji Kolmogorov-Smirnov, diperoleh skor $\mathrm{p}$ lebih besar dari $0,05(p=0,200)$ sehingga peneliti menyimpulkan bahwa data terdistribusi dengan normal.

\section{Uji normalitas variabel kecenderungan delinkuensi}

Selanjutnya, peneliti juga melakukan uji normalitas untuk variabel kecenderungan delinkuensi dengan menggunakan uji Kolmogorov-Smirnov. Berdasarkan hasil pengujian, diperoleh skor $p$ lebih besar dari 0,05 ( $p=0,200)$ sehingga disimpulkan bahwa data terdistribusi dengan normal.

Tabel 2. Uji Normalitas Kedua Variabel

\begin{tabular}{lc}
\hline Variabel & Skor $\mathbf{p}$ \\
\hline Student engagement & 0,200 \\
Kecenderungan delinkuensi & 0,200 \\
\hline
\end{tabular}

\section{Uji korelasi}

Berdasarkan hasil uji normalitas, diketahui bahwa kedua variabel terdistribusi dengan normal. Oleh karena itu, uji korelasi yang digunakan adalah uji korelasi Pearson (parametrik). Hasil uji Pearson menunjukkan bahwa terdapat hubungan yang signifikan antara student engagement dan kecenderungan delinkuensi, dan hubungan antara keduanya memiliki arah negatif $(\mathrm{r}=-0,547, \mathrm{p}$ $=0,000)$. Hal ini berarti, semakin tinggi student engagement, maka semakin rendah kecenderungan delinkuensi pada remaja; sebaliknya semakin rendah student engagement, maka semakin tinggi kecenderungan delinkuensi pada remaja.

Hal ini sesuai dengan Kartono (2014) yang menyatakan bahwa remaja yang jenuh dan bosan dengan sekolahnya akan cenderung berperilaku delinkuen. Penelitian ini juga selaras dengan penelitian dari Wang dan Fredericks (2014) yang menemukan bahwa siswa yang tidak engaged akan mencari pelampiasan dengan cara mencari lingkungan pertemanan yang problematik.

\section{KESIMPULAN DAN SARAN}

\section{Kesimpulan}

Hasil riset ini menyimpulkan bahwa terdapat hubungan yang signifikan dan negatif antara student engagement dengan kecenderungan delinkuensi pada remaja. Hal ini berarti, siswa dengan student engagement yang tinggi memiliki kecenderungan delinkuensi yang rendah, sedangkan siswa dengan student engagement yang rendah memiliki kecenderungan delinkuensi yang tinggi. Hal ini sejalan dengan pernyataan Kartono (2014) bahwa salah satu faktor yang memengaruhi perilaku delinkuen pada remaja adalah ketidakpuasan remaja terhadap sekolah. Selain itu, temuan dari penelitian ini juga sesuai dengan hasil penelitian Wang dan Fredericks 
(2014) yang menemukan bahwa kegagalan siswa untuk engaged dengan sekolahnya dapat menyebabkan siswa mencari pelampiasan dengan perilaku-perilaku yang problematik.

\section{Saran}

Secara praktis, peneliti menyarankan agar baik orangtua maupun guru memerhatikan student engagement remaja agar bisa terjaga dari delinkuensi remaja, sesuai dengan hasil penelitian ini yang menemukan bahwa student engagement berhubungan secara negatif dengan kecenderungan delinkuensi pada remaja. Kemudian, untuk penelitian selanjutnya dapat dilakukan dengan jumlah partisipan yang lebih besar untuk mendapatkan data yang lebih baik. Peneliti juga menyarankan untuk melakukan penelitian mengenai kecenderungan perilaku delinkuensi dengan variabelvariabel lainnya yang terkait dengan sekolah, seperti kesejahteraan akademik siswa.

\section{Ucapan Terima Kasih (Acknowledgement)}

Peneliti mengucapkan terima kasih kepada berbagai pihak yang telah mendukung penelitian ini, terutama kepada para kepala sekolah yang telah mengizinkan peneliti untuk melakukan pengambilan data dan kepada para partisipan penelitian yang telah bersedia untuk memberikan informasi kepada peneliti.

\section{REFERENSI}

Amelia M., \& Hariyanto, I. (2017, Februari 24). Tawuran pelajar di Jaktim, 1 orang tewas. Detik News. Diambil dari https://news.detik.com/berita/d-3431303/tawuran-pelajar-di-jaktim-1orang-tewas.

Anugrahadi, A. (2017, Mei 30). Sempat ditangkap saat razia di Depok, 2 remaja diizinkan pulang. Liputan 6. Diambil dari http://news.liputan6.com/read/2971273/sempatditangkap-saat-razia-di-depok-2-remaja-diizinkan-pulang

Arifin, Z. (2017, Maret 9). Heboh aksi mesum pelajar-pelajar di Jatim. Liputan 6. Diambil dari http://regional.liputan6.com/read/2881005/heboh-aksi-mesum-pelajar-pelajar-di-jatim

Fredricks J.A., Blumenfeld P.C., Paris A.H. (2004). School engagement: Potential of the concept, state of the evidence. Review of Educational Research, 74, h.59-109.

Hariyanto, I. (2017, Juni 18). Polisi tangkap 63 pemuda yang akan tawuran di Jakarta Timur. Detik News. Diambil dari https://news.detik.com/berita/d-3534277/polisi-tangkap-63pemuda-yang-akan-tawuran-di-jakarta-timur.

Kartono, K. (2014). Patologi sosial II: Kenakalan remaja. Jakarta: Rajawali Press.

Sarwono, S., W. (2013). Psikologi remaja. Jakarta: Rajawali Press.

Skinner, E.A., Kindermann, T.A., Connell, J.P., \& Wellborn, J.G. (2009). Engagement as an organizational construct in the dynamics of motivational development. Dalam K.R. Wentzel \& D.B. Miele (Eds.), Handbook of motivation at school. New York, NY: Routledge.

Wang, M.T., \& Holcombe, R. (2010). Adolescents' perception of school environment, engagement, and academic achievement in middle school. Educational Research Journal, 47(3), h.633-662. 